\title{
Strategies to Minimize the Impact of Antibiotic Resistance in Livestock Production System
}

\author{
Ankaj Thakur ${ }^{1 *}$, Atul Kumar ${ }^{2}$, Manoj Sharma ${ }^{3}$, Rohit Kumar ${ }^{4}$ and Brij Vanita ${ }^{5}$ \\ ${ }^{1}$ Department of Livestock Farm Complex, ${ }^{2}$ Department of Vety Public Health \& \\ Epidemiology, ${ }^{3}$ Department of VAHEE, ${ }^{5}$ Department of Veterinary Anatomy, CSKHPKV, \\ Palampur, India \\ ${ }^{4}$ LPM, ICAR-NDRI, Karnal, Haryana, India \\ *Corresponding author
}

\section{A B S T R A C T}

Antibiotics play an indispensable role in animal health, welfare and production management. They find their place is as sub-therapeutic, prophylactic, metaphylactic and therapeutic agents for use in livestock sector. However, the possibility for transfer of

Keywords

Livestock production system, Antibiotic resistance

Article Info

Accepted:

20 February 2019

Available Online:

10 March 2019 antibiotics resistance genes among livestock through food chain and environment is probably a direct threat to public health. This review focuses on the prudential use of antibiotics and advocating various practices which can potentially minimize the usage of antibiotics in livestock production system. Adopting good husbandry practices (GHP), organic livestock production, manure management practices, regular testing of antibiotic residues in food of animal origins, using alternative to antibiotic growth promoters (AGP) are among the promising practices to minimize the need of antibiotics. This will eventually help in reducing contribution of livestock sector towards emergence of antibiotic resistance. Prophylactic alternatives (vaccines, immune modulators, phage therapy), therapeutic alternatives (selective dry cow therapy, supplementation of vitamins and minerals, ozone therapy, ethno veterinary practices, rare earth elements) and implementing good veterinary practices (GVP) can also support mankind's effort in combating antibiotic resistance. Finally, increasing consumer awareness and strengthening the regulatory control of antibiotic usage will definitely prove fruitful in containment of emerging problems associated with antibiotic resistance.

\section{Introduction}

Antibiotics are the most commonly used and abused antimicrobial agents all around the world. Livestock production system is one of the largest consumers of antibiotics (Pruden et al., 2013). In livestock production, antibiotics are mainly used for disease treatment, disease prevention and growth promotion (Paige et al., 1997; Kumar et al., 2018). India was among the top five countries, using $3 \%$ of the global share of antibiotics in animal-food production (Boeckel, 2015). Antibiotics are widely used in India, which could be 
attributed to poor biosecurity practices leading, to high incidence of infectious diseases and partly due to indiscriminate use of such drugs by unskilled non-professionals (Okele et al., 1999). Increased demand for animal protein and resulting intensification of food animal production is further responsible for greater use of antibiotics in livestock production system.

Indiscriminate use of antibiotics in food producing animals have led to emergence and dissemination of antibiotic resistance bacteria via food chain, direct contact and direct and indirect contact with waste or other transmission routes (WHO, 2014; O'Neill, 2015). Regular use of antibiotics has serious consequences on human beings since residue of antibiotics may accumulate in food of animal origin such as milk, meat and eggs for considerable period of time. As per World Health Organization, antibiotic resistance refers specifically to resistance to the antibiotics that occurs in common bacteria that cause infections while antimicrobial resistance is a broader term, encompassing resistance to drugs to treat infections caused by other microbes as well, such as parasites (e.g. malaria), viruses (e.g. tuberculosis and HIV) and fungi (e.g. Candida). AMR is a product of natural selection in bacteria, their survival abilities. Genetic variation in microbes may carry mutations which render antibiotics ineffective. Methicillin-resistant Staphylococcus aureus (MRSA) has been found in 12 percent of animal products - beef, veal, lamb, pork, and a variety of fowl-in Denmark, and in dairy products in Italy (De Boer et al., 2009; Normanno et al., 2007). In India, 100 percent resistance to sulfadiazine was detected in Pasteurella multocida isolates in chickens and other fowl, and resistance to amikacin, carbenicillin, erythromycin, and penicillin was also widespread (Shivachandra et al., 2004). Resistance has also been reported in Staphylococcus and other bacteria in poultry litter. According to one study conducted by Dhanarani et al., (2009), 75 percent of isolates of bacteria from poultry litter samples were resistant to streptomycin, and more than 50 percent were resistant to erythromycin, tobramycin, and ampicillin (Dhanarani et al., 2009).

In developing countries like India, where the optimal biosecurity is not maintained in animal farms, antibacterial drugs remain the mainstay for the treatment of ensuing bacterial infections. Prophylactic or metaphylactic use of antibiotics can be a substantial aid in the control and prevention of livestock diseases. However, this use of antibiotics should never be intended to replace the need for good management practices, given that the use of antibiotics will eventually lead to emergence of resistance. For prudent use of antibiotics, principle guidelines need to be created to prevent abusive use of antimicrobials, primarily to curb or mitigate the imminent risk of breeding resistant microorganisms. This review focuses on the prudential use of antibiotics and promoting various practices which minimize the use of antibiotics for reducing the contribution of livestock sector towards emergence of antibiotic resistance in livestock production system and finally to safeguard the human health.

\section{Dissemination of antibiotic resistance}

Rapid emergence and dissemination of resistant bacteria and genes among humans, animal and the environment has led the antibiotic resistance being recognized as 'One Health' challenge (Robinson et al., 2016). Indiscriminate use of antibiotics in livestock production system will affect human health in two ways, firstly by causally linked contact with antibiotic resistant organism and secondly by contact with resistant organisms that have entered the ecosystem (water, soil) 
as a result of antibiotic misuse in food animals. Antimicrobial resistant bacteria may be transferred from livestock to humans, through animal to human contact, through environment and most importantly through contaminated food products (CAC, 1998). Antibiotic resistance can be transferred among bacteria that infect livestock and humans through three forms of horizontal gene transfer (Transformation, Transduction and Conjugation). Commensal bacteria found in livestock are frequently present in fresh meat products and may serve as reservoirs for resistant genes that could potentially be transferred to humans (Mena et al., 2008; Diarrassouba et al., 2007). Due to normal genetic variation in bacterial populations; individual organisms may carry mutations that render antibiotics ineffective, conveying a survival advantage to the mutated strain. Pathogenic resistant organisms propagated in these livestock are poised to enter the food supply and could be widely disseminated in food products (Garofalo et al., 2007; Ramchandani et al., 2005). Identical strains of antibiotic-resistant bacteria have been found in farm animals and farm workers (Zhang et al., 2010). Staphylococcus aureus (including methicillin-resistant Staphylococcus aureus) and Clostridium difficile found in livestock and can later be found in food products and environments shared with humans (WHO, 2014).

\section{Public health crisis of antibiotic resistance}

Exposure of antibiotics has negative effect on human health and environment (Saad, 2016). The possibility for transfer of antibiotics resistance genes among livestock is a potential threat to the public health. Two $\beta$ lactam antibiotics (penicillin and cephalosporin) can cause cutaneous eruptions, dermatitis, gastro-intestinal symptoms and anaphylaxis at very low doses (Paige et al., 1997). Heat processing of milk does not eliminate or degrade antibiotic residues contained in milk (De Oliveira et al., 2012). Some antibiotics have side effects on consumers and therefore consumption of milk containing antibiotic residues can cause some complications among milk consumers. Examples of such complications are allergies such as urticaria, dermatitis, asthma and rhinitis (Nero et al., 2007). This represents a potential risk to consumers of milk containing antibiotic residues (Movassagh and Karami, 2010). Soil, surface and ground water can also have transformed antibiotic residues which travel via many routes such as sub-surface flow, drain flow or leaching (Kim et al., 2011; Botelho et al., 2015). This can lead to accumulation of antibiotics in the edible plant and can pose risk to crop, soil and water ecosystem (Ahmed at al., 2015; Costanzo et al., 2005; Jalal et al., 2012). On the other hand, pharmaceutical companies are also focusing their major research and development activities towards managing lifestyle related problems (diabetes, heart disease) as it fetch them more profit, but not on making of new generation antibiotics which are important for lethal infections. Without antibiotics, surgeries, chemotherapy, autoimmune disease treatment might not be possible because risk of getting infection will be too high. Therefore, there is a growing awareness of public health concern associated with the use of antibiotics in animal husbandry and antibiotic resistance is emerging as a potential threat in coming time.

\section{Alternative strategies to reduce antibiotic resistance in livestock farming}

The following strategies can be used to reduce the antibiotic resistance in livestock farming

\section{Adopting good husbandry practices (GHP)}

Most important factor in reducing antibiotic use is knowledgeable animal husbandry 
practices (Van de Weerd et al., 2009). Antibiotics should not be used as a substitute for the good managemental practices (Wierup, 2001) e.g. Good management practices and colostrum feeding is useful in preventing scours in calves. Major factors responsible for developing antimicrobial resistance in farm environment isolates are excessive usage of antibiotics, over-crowding and poor sanitation (Forsberg et al., 2012). Good animal husbandry practices at farm comprise of safe animal feed, animal health and welfare, and healthy living conditions. Management practices viz. improving hygiene, proper stocking density, minimizing stress, biosecurity, water and feed quality, identification and record keeping etc. will help in disease control and minimizing the use of antibiotics as growth promoters. Animal health status should also be assessed with regard to any infectious agent that they could be harboring at the primary stage of production.

\section{Adopting organic livestock farming as alternative production system}

The intensive livestock production methods are mainly blamed for the increased problem of antibiotic resistance in human health and shift towards this system will increase antimicrobial consumption in animals up to one third between 2010 and 2030 (Maron et al., 2013; Silbergeld et al., 2008). Sapkota et al., (2011) have observed that following a conversion to organic feed, multidrug resistance rates of Enterococcus faecium decline from $84 \%$ to $17 \%$. Conventional production system has higher concentration of the AMR levels when compared to the organic (Mazurek et al., 2013; Cui et al., 2005; Holtcamp, 2011). However, Gebreyes et al., (2005) reported higher prevalence of Campylobacter species in the outdoor flocks when compared to the indoor due to horizontal transmission via the open environment where the pigs have unrestricted access to the soil and water.

Organic Dairy farming means raising animals on organic feed (i.e. pastures cultivated without the use of fertilizers or pesticides), have access to pasture or outside, along with the restricted usage of antibiotics and hormones (Oruganti, 2011). In organic farming mainly local, native and pure breeds are used which are more adapted to the prevailing conditions and show robustness against many endemic infectious diseases. Moreover the organic management system is based on preventive herd health management and use of alternative medicine. This will indirectly reduce the usage of antibiotics in livestock production system. The withdrawal periods before milking and slaughter is usually kept longer. This will alleviate the selection pressure that drives the proliferation of antibiotic resistance bacteria. Therefore, the organic farming with better biosecurity and high herd health and indoor feeding should be encouraged by providing the incentives to the farmers and by developing marketing channels for organic livestock products.

\section{Manure management practices}

A high proportion of antibiotics are excreted by the livestock in form of urine or feces and its application on land will further alter the environment microbial ecosystem (Levy, 1992; Kumar et al., 2005; Giger et al., 2003). Between $30 \%$ and $90 \%$ of antibiotics fed to animals are excreted in animal feces and urine, as most of the antibiotics are water soluble (Heberer, 2002; Sarmah et al., 2006; Thiele-bruhn 2003). Composting helps in eliminating on an average $50-70 \%$ of some antibiotics (Sharma et al., 2009; Storteboom et al., 2007; Wang et al., 2012). Long-term manure storage offers benefits in terms of containment and can result in reduced 
prevalence of tetracycline residues and tetracycline resistant bacteria (CheeSanford et al., 2009). Watering, aeration and turning of compost offered some advantage to accelerate antibiotic delay of chlortetracycline, monensin and tylosin, yet even basic stockpiling of manure resulted in significant antibiotic degradation (Storteboom et al., 2007).

\section{Regular testing of antibiotic residues}

Regular testing for the antibiotic residues should be done for the products of animal origin e.g. testing loads of milk for antimicrobial residues ensure that milk containing residue does not inadvertently enter the food supply (Wary and Gnanou, 2000). Analytical method in antibiotic residues are generally divided into two types - screening (inexpensive, rapid but do not provide unequivocal identification) and confirmatory methods (expensive, consuming and highly selective in order to provide unequivocal identification). These are Charm inhibition assay, Delvotest, assay, biosensors, liquid chromatography, gas chromatography, thin layer chromatography, high performance liquid chromatography and mass spectrometry (Kumar et al., 2018). Traditional screening assays are based on the growth inhibition of microorganism (e.g. Bacillus Stearothermophilus) by antibiotic residues present in the test sample. The combination of bio-based screening method and an instrumental confirmatory method hold very strong in residue analysis.

\section{Using alternatives to antibiotic growth promoters (AGP)}

Antibiotic growth promoters (AGP) are the chemical substances which are added to livestock food primarily to control diseases and more recently to promote growth and improve feed conversion (Peric et al., 2009;
Eseceli et al., 2010). They primarily destroy or inhibit bacteria and are usually administered at low, sub therapeutic doses as a feed supplement. The AGP also inhibit endemic subclinical infection by controlling growth and proliferation of microorganisms in the host species, thus preventing diseases (Oguttu et al., 2007). However, the efficacy of the antibiotics for growth promotion is diminishing when compared to the past (Laxminarayan, 2015). Issue of development of antimicrobial resistance and transference of antibiotic resistance genes from animal to human microbiota, resulted in withdraw approval for use of antibiotics as growth promoters in the European Union since 2006. There is a need to look for viable alternatives that could enhance the natural defense mechanisms of animals and reduce the massive use of antibiotics. Use of alternative AGP (Table 1) such as probiotics, prebiotic and symbiotic as a growth promoter is safe and don't have negative impact on the natural environments (Markowiak and Slizewska, 2018).

\section{Prophylactic alternatives for livestock production}

\section{Vaccines}

Vaccination is one of the most cost effective methods for disease prevention as it prevent bacterial infections directly and reduce the need for antibiotics. Indirectly vaccines also provide herd immunity, which extends the protection to the unvaccinated livestock. In one study on 64 farms in 9 European countries, the majority of pig operations experienced cost reductions for antibiotic treatment after L. intracellular vaccination (Adam, 2009). Vaccination for porcine circovirus type 2 in Australian pig herds leads to significant decline in total antimicrobial drug use, as the pigs had less immunosuppression and secondary bacterial 
infections (Raith et al., 2016). Vaccines can be a good candidate for replacement of growth promoting antibiotic especially during the post-weaning period in which maximum production losses occurs. Cost and ease of vaccine usage will further improve the acceptability of this alternative for antibiotics. In developing nations like India, more focus should be given to spreading the knowledge of vaccine usage for the livestock, increase vaccine coverage and development of newer effective vaccines for the endemic diseases.

\section{Phage therapy}

In phage therapy, mechanism of lytic phase (physical breakdown of bacteria for escape of progeny virus) is used to kill the pathogenic bacteria. These are more specific to the target bacteria than antibiotic therapy and hence can be a potential therapeutic agent. Phage cocktail comprised of group of virus can be used as an effective tool for combating the antibiotic resistance. Moreover these have less side-effect on the eukaryotic cells. In an attempt to reduce shedding of $S$. enteritidis in the poultry, Phage PSE has been successfully used as an alternative to the antibiotics (Ahmadi et al., 2016).

\section{Immune modulators}

Immune modulators (e.g. synthetic CpGcontaining oligodeoxynucleotides, Antimicrobial peptides etc.) elicit passive immune response by transfer of antibodies. In contrast to vaccines, immune modulators stimulate immune system in a way that is less dependent on the pathogen causing infection, which makes them effective for a broad range of pathogens (Koo et al., 2006). Synthetic CpG-containing oligodeoxynucleotides (CpGODN)/Bacterial DNA have shown immunoprotective effect against extracellular bacterial infection in poultry (Weiner et al., 1997). CpG ODNs fortify the immune system to mount a quick innate immune response and advances the $\mathrm{T}$ helper 1 protective immunity (He et al., 2006). AMPs (Antimicrobial peptides) particularly the bacteriocins have a broad-spectrum activity against microorganisms and thus can provide a nonspecific defense against the infections. These work by directly attacking microbes, maintenance of normal gut homeostasis and modulation of host inflammatory responses (Wang et al., 2016).

\section{Therapeutic alternatives for livestock}

\section{Selective dry cow therapy}

Globally, mastitis treatment is the main reason for antibiotics usage in dairy production systems. Though, the modern commercial dairy farming increased the milk production, it also increased the incidence of mastitis in dairy animals. $16 \%$ of all lactating dairy cows in the U.S. receive antibiotic therapy for clinical mastitis each year, but nearly all dairy cows receive intramammary infusions of prophylactic doses of antibiotics following each lactation to prevent and control future mastitis. The major antimicrobial agents used for this purpose are penicillins, cephalosporins and betalactam drugs (USDA 2008). In blanket dry cow therapy (DCT) all the quarters of cows are treated while in selective DCT infected cows are treated with antibiotic along with teat sealant and uninfected cows are treated with teat sealant only. Cattle having low risk of mastitis $\left(1^{\text {st }}\right.$ or $2^{\text {nd }}$ lactation cattle with low somatic count) are not treated, and cattle at low risk of successful treatment with dry-cow therapy (older cattle with high somatic count) are recommended for culling. Compared to blanket antibiotic DCT, group of cows receiving selective DCT (on basis of Somatic cell count and aerobic bacterial count) had a reduction in usage of antibiotics but showed no significant difference regarding new intramammary infections (Tho seeth et al., 2017). 


\section{Supplementation of minerals and vitamins}

Supplemental Selenium and Vitamin E during the peripartum period improves the immune function of the dairy cattle. Selenium and Vitamin E improves overall neutrophil function, enhance the ability to kill E. coli and $S$. aureus and improve the neutrophil chemotaxis (Hogan et al., 1990; Politis et al., 1996; Politis et al., 1995). Dietary supplementation of $\mathrm{Cu}(180 \mathrm{mg} /$ day $)+\mathrm{Zn}$ (300 mg/day) +Vitamin E (500 IU/day) + selenium $(6 \mathrm{mg} /$ day $)+$ Vitamin A $(53000$ IU/day) + beta carotene (300 mg/day) during last 2 month of gestation is beneficial for control of sub-clinical mastitis in dairy cattle (Sahu and Maiti, 2014). Supplementation of $2500 \mathrm{ppm}$ Zinc reduced the incidence of nonspecific diarrhea in weaning piglets (Poulsen 1995)

\section{Ozone therapy}

Ozone $\left(\mathrm{O}_{3}\right)$ is an unstable polymerized oxygen which is created by the passage of air or oxygen over high energy electrodes within an ozone generator system or by ultraviolet light (Shinozuka et al., 2008). Ozone disrupts cell membrane of microbes and kills viruses by diffusing through the protein coat of nucleic acid. Ozone foam has a potential to alleviate metritis, mastitis and endometritis (Duricic et al., 2014). Ozone therapy was found to be more responsive in uterine infection than use of gentamicin in crossbred dairy cattle (Durrani et al., 2017). In an in vitro study done by Fontes et al., (2012) on potentially pathologic bacterial strains with known resistance to known antimicrobial agents, a single topical application by nebulization of a low ozone dose was found to completely inhibit the growth of all potentially pathogenic antimicrobial resistant bacterial strains. Therefore, ozone may prove to be a useful alternative to antibiotics with better results in inhibiting the growth of antimicrobial resistant bacterial strains.

\section{Ethno veterinary practices}

Ethno veterinary practices concern to animal healthcare is as old as the domestication of various livestock species. Ethno-veterinary practices (EVP) include herbal medicine as well other locally adapted practices in animal health care. EVPs can be advocated in primary health care of livestock, this practice will minimizes the possibility of antibiotic residues in the livestock products (Ranganathan, 2017). In Cattle suffering from FMD, paste prepared from the leaves of Nicotiana tabacum (tobacco), decoction of the fruit Terminalia chebula or Harida or tarlike oil extracted from the pericarp of the fruit Semecarpus anacardium can be applied on hoofs (Chakraborty and Pal, 2012). Seeds of Cucurbita maxima were also found to have immunomodulatory effects in rabbits when used @ $1000 \mathrm{mg} / \mathrm{kg}$ orally for 10 days (Ranganathan and Selvasubramanian, 2015)

\section{Rare earth elements}

Rare earth elements (REE) include the elements scandium, yttrium, lanthanum and the 14 chemical elements following lanthanum called lanthanides (Foerster et al., 2008). REE had a high anti-oxidative effect and therefore protect dietary fatty acids from oxidization and increased uptake of nutrients. In diet, these significantly improve body weight and feed conversion (Redling, 2006). Rare earth mineral and yeast (Saccharomyces cerevisiae) feeding in pigs had equal performance when compared with $\mathrm{ZnO}$ and antibiotic supplementation, wherein the effect of mineral-yeast combination was mediated through improvement in nutrient digestibility (Han et al., 2010).

\section{Implementing good veterinary practices (GVP)}

Antibiotic should be prescribed by the veterinarian only after proper disease 
diagnosis and appropriate antibiotic should be chosen after testing sensitivity (De Briyne et $a l ., 2013)$. Isolation of the animal from the herd and their individual treatment is required to be followed in every farm premises. Based on sensitivity testing, narrow spectrum drug should be the first choice for treatment. Broad spectrum antibiotic should only be chosen when narrow spectrum antibiotic exhibit insensitivity (EU, 2015). Metaphylactic treatment in herd or flock should only be prescribed on the basis of clinical findings about the progress of disease (Trevisi et al., 2014). It is also important to administer the antibiotics as per instructions of the prescriber and manufacturer of the drug (Stanton et al., 2010)

\section{Following recommended Withdrawal period and Maximum residue limits (MRLs)}

For prevention and control of antimicrobial residues, veterinarians and producers should stick to the prescribed withdrawal periods of antimicrobial agents and test presence of residues when necessary. Withdrawal period is the time between the last doses given to the animal and the time when the level of residues in the tissues (muscle, liver, kidney, skin and fat) and products (milk, eggs, honey) is lower or equal to the maximum residual limits (MRLs).

Until the withdrawal period has elapsed, the animal or its products must not be used for human consumption (Jackson 1980). The minimum withholding period for milk and egg is 7 days and for meat is 28 days after treatment with antibiotics (Gupta, 2012). The maximum residue level (MRLs) is the maximum concentration of residue resulting from the use of a veterinary medicinal product that may be legally permitted or recognized as acceptable in or on a food, allocated to individual food commodities The MRLs are fixed on the basis of relevant toxicological data (EEC, 1990).

\section{Strengthening the regulatory control for antibiotic usage in livestock}

Internationally, from 2006, European Union has banned antibiotic use in growth promotion while it is illegal in the US from 2017. FAO and WHO has developed the Codex Alimentarius which specifies a series of recommendations to 'ensure safety and quality in international food trade. In 2015, the MRLs for veterinary drugs including antibiotics in foods were updated by Codex Alimentarius Commission. Also, The World Organization for Animal Health (OIE) has three major texts that deal with antibiotic resistance: the Terrestrial Animal Health Code, the Aquatic Animals Health Code and the Manual of Diagnostic Tests and Vaccines for Terrestrial Animals (OIE 2015b; OIE 2015a; OIE 2008).

In India, as per the Food Safety and Standards Act, 2006, no article of food shall contain pesticides, veterinary drugs, antibiotic residues, and microbiological counts in excess of such tolerance limits as may be specified by regulations (Government of India, 2006). In India, AMR related policies were initiated in 2011 by publishing the National Policy on containment of AMR.

The Food Safety and Standards (Contaminants, Toxin and Residues) Regulation came in to force on $5^{\text {th }}$ Aug, 2011 and deals with the compliance of various contaminants, Toxins and Residues Standards prescribed in food. This regulation has provided tolerance limit for antibiotics and also the list of prohibited pharmacologically active substances in fish and fishery products. There are two laws in India for regulating antibiotic use in livestock. 
Table.1 Promising alternatives to antibiotics for growth promotion

\begin{tabular}{|c|c|c|c|c|}
\hline $\begin{array}{l}\text { Alternatives } \\
\text { to antibiotic } \\
\text { growth } \\
\text { promoters }\end{array}$ & Examples & Mode of action & Effect of AGP on performance & Reference \\
\hline $\begin{array}{l}\text { Probiotics/ } \\
\text { Direct-fed } \\
\text { Microbials } \\
\text { (DFMS) }\end{array}$ & $\begin{array}{l}\text { Gram positive bacteria- } \\
\text { Bacillus, Enterococcus, } \\
\text { Lactobacillus, } \\
\text { Pediococcus, } \\
\text { Streptococcus (usually } \\
\text { present in amount of } \\
10^{7}-10^{8} \text { and } 10^{5}-10^{6} \\
\text { CFU/g) } \\
\text { Fungi and yeast strain- } \\
\text { Saccharomyces } \\
\text { cerevisiae and } \\
\text { Kluyveromyces species }\end{array}$ & $\begin{array}{l}\text { 'Live microbial feed } \\
\text { supplements', which affects } \\
\text { the host animal by } \\
\text { improving its intestinal } \\
\text { microbial balance (Fuller, } \\
\text { 1989) }\end{array}$ & $\begin{array}{l}\text { In young calves, it has been observed } \\
\text { that by incorporating live yeasts into } \\
\text { the grain, there is marked reduction in } \\
\text { number of days with diarrhea } \\
\text { Two different probiotic preparations, } \\
\text { containing six Lactobacillus spp. of } \\
\text { bovine and human origin, were } \\
\text { successful in reducing the overall } \\
\text { mortality, incidence of diarrhea and } \\
\text { fecal coliforms counts in veal calves } \\
\text { Growth performance of weaning } \\
\text { piglets is improved by feeding Probitic } \\
\text { strains of Bifidobacterium animalis } \\
\text { subsp. Lactis Ra } 18 \text { at } 10^{11} \text { CFU per } \\
\text { pig per day }\end{array}$ & $\begin{array}{l}\text { Galvao et al., } \\
2005 \\
\text { Timmerman et } \\
\text { al., } 2005 \\
\text { Modesto } \text { et al., } \\
2009\end{array}$ \\
\hline Prebiotic & $\begin{array}{l}\text { Fructo- } \\
\text { oligosaccharides } \\
\text { (FOS), oligofructose, } \\
\text { trans-galacto- } \\
\text { oligosaccharides } \\
\text { (TOS), gluco- } \\
\text { oligosaccharides }\end{array}$ & $\begin{array}{l}\text { Non-digestible food } \\
\text { components/ingredients } \\
\text { which have positive effect } \\
\text { on host in their selective } \\
\text { growth and/or activation of } \\
\text { certain number of bacterial } \\
\text { strains present in intestines } \\
\text { (Peric et al., 2009) }\end{array}$ & $\begin{array}{l}\text { Oligosaccharides (chitosan and } \\
\text { galacto-manannan-oligosaccharides) } \\
\text { improve growth and feed efficiency by } \\
\text { increasing growth hormone and } \\
\text { insulin-like growth factor-I levels, in } \\
\text { the early-weaned piglets } \\
\text { Although, the use of prebiotics in } \\
\text { ruminants has been unsuccessful due } \\
\text { to their ability to degrade most } \\
\text { prebiotics in rumen. However, } \\
\text { enhancements in rumen-protective } \\
\text { technologies may allow these } \\
\text { compounds to be used in feedlot and } \\
\text { dairy cattle }\end{array}$ & $\begin{array}{l}\text { Callaway } \\
\text { al., } 2008\end{array}$ \\
\hline Synbiotics & $\begin{array}{lr}\text { Combination } & \text { of } \\
\text { Bifidobacterium } & \text { or } \\
\text { Lactobacillus genus } \\
\text { bacteria with FOS }\end{array}$ & $\begin{array}{l}\text { Combination of nutritional } \\
\text { supplement containing both } \\
\text { probiotic and probiotic is } \\
\text { called symbiotic. Growth of } \\
\text { the co-administered } \\
\text { probiotic or other useful } \\
\text { microbes may be promoted } \\
\text { by the prebiotic present in } \\
\text { the symbiotic product }\end{array}$ & $\begin{array}{l}\text { When a combination of probiotic and } \\
\text { prebiotic added to the milk, a better } \\
\text { improvement in average daily gain and } \\
\text { more decrease in fecal E. coli has also } \\
\text { been reported in female calves }\end{array}$ & $\begin{array}{l}\text { Roodpshti and } \\
\text { Dabri, } 2012\end{array}$ \\
\hline $\begin{array}{l}\text { Phytogene } \\
\text { additives }\end{array}$ & $\begin{array}{l}\text { Essential oil or tannins } \\
\text { Substances deriving } \\
\text { from medicinal plants } \\
\text { or spices }\end{array}$ & $\begin{array}{l}\text { PFA (Phytogenic feed } \\
\text { additives) augment nutrient } \\
\text { utilization in the } \\
\text { gastrointestinal tract (GIT) } \\
\text { by enhancing production of } \\
\text { digestive secretions and } \\
\text { enzymatic activity }\end{array}$ & $\begin{array}{l}\text { Phytogene additives have positive } \\
\text { effect on production and health of } \\
\text { animals. Phytochemicals have efficacy } \\
\text { for the prevention of diseases in cattle } \\
\text { such as diarrhea and to improve } \\
\text { digestive health }\end{array}$ & $\begin{array}{l}\text { Ghosh et al., } \\
\text { 2013; Vakili et } \\
\text { al., } 2013 \\
\text { Murugesan et } \\
\text { al., 2015 }\end{array}$ \\
\hline
\end{tabular}




\begin{tabular}{|c|c|c|c|c|}
\hline & & $\begin{array}{l}\text { Windisch et al., 2007). } \\
\text { PFA, like AGP, may also } \\
\text { reduce mucosal thickness, } \\
\text { thus contributing to the } \\
\text { diffusion of nutrients to the } \\
\text { apical surface of epithelial } \\
\text { cells and increased } \\
\text { absorption and feed } \\
\text { efficiency (Yang et al., } \\
\text { 2015) }\end{array}$ & $\begin{array}{l}\text { PFA showed comparable result to } \\
\text { AGP for improving the body weight } \\
\text { gain and lowered the feed conversion } \\
\text { ratio (FCR) }\end{array}$ & \\
\hline Organic acid & Citric acid, Acetic acid & $\begin{array}{l}\text { Organic acid reduce pH of } \\
\text { intestinal tract which favors } \\
\text { growth of favorable } \\
\text { microbes which in turn } \\
\text { suppress } \\
\text { microbes }\end{array}$ & $\begin{array}{l}\text { Formic acid, acetic and propionic acid } \\
\text { have the potential to reduce the } \\
\text { Salmonella and Campylobacter } \\
\text { colonization in the gut of poultry } \\
\text { Acidifiers also improve growth } \\
\text { performance and immunity in } \\
\text { livestock. Acidification of the diet } \\
\text { with protected organic acid blends } \\
\text { positively affected the ADG and } \\
\text { reduced pathogenic bacterial load in } \\
\text { finishing pigs }\end{array}$ & $\begin{array}{l}\text { Griggs and } \\
\text { Jacob, } 2005 \\
\text { Upadhaya et } \\
\text { al., } 2014\end{array}$ \\
\hline $\begin{array}{l}\text { In feed- } \\
\text { Enzymes }\end{array}$ & $\begin{array}{l}\text { Xylanases and beta- } \\
\text { glucanases }\end{array}$ & $\begin{array}{l}\text { In-feed enzymes promote } \\
\text { the digestion of feed } \\
\text { components that are poorly } \\
\text { digested or undigested. } \\
\text { They are mainly added to } \\
\text { the wheat and barley based } \\
\text { diets. }\end{array}$ & $\begin{array}{l}\text { In feed enzymes are mostly added in } \\
\text { the poultry as they have limited ability } \\
\text { to digest NSPN (Non starch } \\
\text { polysaccharides), due to lack of } \\
\text { enzymes. Also, help in preventing } \\
\text { certain diseases such as necrotic } \\
\text { enteritis } \\
\text { In swine, these show inconsistent } \\
\text { results as to high level of acidity may } \\
\text { inactivate in-feed enzymes }\end{array}$ & $\begin{array}{l}\text { Kiarie et al., } \\
2013 \\
\text { Thacker, } 2013\end{array}$ \\
\hline
\end{tabular}

First regulation is regarding the withdrawal period of medicines that are used in treatment of animals. This regulation states that withdrawal period should be mentioned in the labeling of medicines as per Ministry of Health and Family Welfare (2012). In case there is no defined withdrawal period, the period should be 28 days in meat and poultry products. Second regulation is regarding requirement of prescription for use of some drugs those falls under the category of Schedule-H drugs as per Ministry of Health and Family Welfare (2006). This category contains a list of 536 drugs as per the Amendment of the Drugs and Cosmetics Rules (2006). These drugs, which include antibiotics, require by law a prescription for their use as per Ministry of Health and Family
Welfare (2006). In 2017, which was again amended under Food Safety and Standards (Contaminants, Toxins and Residues) Regulations, 2011. According to which, the maximum permissible limits have been specified for the presence of antibiotics and other drugs in meat and meat products including chicken. Finally in 2017, National action Plan banned the antibiotics as growth promoters in India. However, still this plan is not linked to any regulatory action.

\section{Challenges}

There are no laws specifically governing the use of antibiotics in cattle, chicken, and pigs reared for domestic consumption in India. Provision for monitoring antibiotic residues is 
only available for exports under the Residual Monitoring Plan of the Export Inspection Council. Due to extra-label use of veterinary drugs or negligence in obeying withdrawal periods, much higher residues level appears in edible animal products. There is no monitoring mechanism that ensures that veterinary prescriptions are in line with judicious use of antibiotics and are updated based on latest trends in resistance in antibiotics. Relatively little attention has been paid to know the degree and relative impact of antibiotics use in farm animals to the overall problem of antibiotic resistance and public health. Moreover, many of these antibiotics are identical to or closely resemble drugs used in human medicine. Therefore, identifying key areas in which action needed is urgently required to minimize and contain antibiotic resistance.

\section{Raising consumer awareness and responsibility}

Consumer's awareness will surely act as an important drive change against AMR. Nowadays, the consumers are also taking interest in how the livestock products they consume reach their plate and they are becoming aware of the antimicrobial resistance (Brookes-Howell et al., 2012). The farmers should also believe in producing livestock products with highest standards. The awareness among the society through Public health campaigns can lead to growth of more antibiotic free products in the market. Considerable proportion of consumers incorrectly thinks that antibiotics are effective against the viral infections (Cals et al., 2007). All the diseases cannot be cured but the antibiotics usage as some are caused by bacteria and some are also caused by virus/other infectious agent. It is the duty of the animal owner and practitioner to realize the fact that indiscriminate use of antibiotics can lead to antimicrobial resistance. Treating the diseases which generally show good response to antibiotics will further become difficult due to the development of AMR. Therefore, more focus should be given on proper and timely diagnosis of disease and then using the antibiotics with correct dosage.

In conclusion, antibiotics used in animals can pass to humans through complex food chains and can significantly contribute to development of antibiotic resistance. Healthy herd management, adoption of organic livestock production and adequate composting processes for livestock manure is an effective strategy to minimize the discharge of antibiotic residue into the environment. Use of alternatives for antibiotic growth promoter can minimize the antibiotic usage to improve gut health status of livestock through increased immunity. Ethno-veterinary medicines, prophylactic alternatives, therapeutic alternatives and strict quality control measures can also help in reducing antibiotic residues in livestock products. The correct identification of the causative agent of the disease, strict adherence to antibiotic label recommendations, strengthening regulatory control for antibiotics usage and raising consumer awareness will eventually help in combating emerging problems associated with antibiotic resistance.

\section{References}

Adam, M. 2009. A meta-analysis on field experiences with vaccination against Ileitis showing a reduction on antibiotics use. Conference: Eighth International Symposium on the Epidemiology and Control of Foodborne Pathogens in Pork. DOI: 10.31274/safepork-180809-872

Ahmadi, M., Karimi Torshizi, M.A., Rahimi, S and Dennehy, J.J. 2016. Prophylactic bacteriophage administration more effective than post-infection administration in reducing Salmonella enterica serovar enteritidis shedding in 
quail. Frontiers in microbiology. 7, 1253.

Ahmed, M.B.M, Rajapaksha, A.U, Lim, J.E., Vu, N.T., Kim, I.S., Kang, H.M., Lee, S.S and Ok YS. 2015. Distribution and accumulative pattern of tetracyclines and sulfonamides in edible vegetables of cucumber, tomato, and lettuce. J Agric Food Chem. 63(2):398-405

Boeckel, T.P.V., Brower, C., Gilbert, M., Grenfella, B.T., Levin, S.A., Robinson, T.P., Teillanta, A and Laxminarayan, R. 2015. Proceedings of the National Academy of Sciences. 112 (18). 56495654.

Botelho, R.G, Monteiro, S.H and Tornisielo, V.L. 2015. Veterinary antibiotics in the environment. In: Emerging Pollutants in the Environment-Current and Further Implications. InTech publisher, Rijeka, Croatia-EU.

http://dx.doi.org/10.5772/60847

Botsoglou NA, Fletouris DJ. (2001) Drug Residues in Foods. Marcel Dekker, New York.

Brookes-Howell, L., Elwyn, G., Hood, K., Wood, F., Cooper, L., Goossens, $\mathrm{H}$ and Butler, C.C. 2012. 'The body gets used to them': patients' interpretations of antibiotic resistance and the implications for containment strategies. Journal of general internal medicine, 27(7), 766-772.

Callaway, T.R., Edrington, T.S., Anderson, R.C., Harvey, R.B., Genovese, K.J., Kennedy, C.N., Venn D.W and Nisbet, D.J. 2008. Probiotics, prebiotics and competitive exclusion for prophylaxis against bacterial disease. Animal Health Research Reviews. 9: 217-225

Cals, J.W., Boumans, D., Lardinois, R.J., Gonzales, R., Hopstaken, R.M., Butler, C.C and Dinant, G.J. 2007. Public beliefs on antibiotics and respiratory tract infections: an internet-based questionnaire study. $\mathrm{Br} \mathrm{J}$ Gen Pract. 57(545), 942-947.

Chakraborty, S and Pal, S.K. 2012. Plants for cattle health: a review of ethnoveterinary

Chee-Sanford, J.C, Mackie, R.I., Koike, S.,
Krapac, I.G., Lin, Y.F., Yannarell, A.C., Maxwell, S and Aminov, R.I. 2009. Fate and transport of antibiotic residues and antibiotic resistance genes following land application of manure waste. J Environ Qual. 38:1086-1108.

Codex Alimentarius commission (CAC). 1998. General requirements (food hygiene) codex almentarius commission, Rome, pp: 21-30

Costanzo, S.D, Murby, J and Bates, J. 2005. Ecosystem response to antibiotics entering the aquatic environment. Marine Pollution Bulletin. 51:218-223

Cui, S., Ge, B., Zheng, J. and Meng, J. 2005. Prevalence and Antimicrobial Resistance of Campylobacter spp. and Salmonella Serovars in Organic Chickens from Maryland Retail Stores. Applied and Environmental Microbiology, 71: 41084111

De Boer, E., Zwartkruis-Nahuis, J. T., Wit, B., Juijsdens, X. W. De Neeling, A. J., Bosch, T. Et al., 2009. Prevalence of Methicillin-Resistant Staphylococcus aureus in Meat. International Journal of Food Microbiology, 134(1-2):5256. Cited in Marshall and Levy 2011.

De Briyne, N., Atkinson, J., Pokludova, L., Borriello, S.P and Price, S. 2013. Factors influencing antibiotic prescribing habits and use of sensitivity testing amongst veterinarians in Europe. The Veterinary Record. 173(19): 475-488

De Oliveira, L.P., Barros, L.S.S., Silva, V.C and Cirqueira M.G. 2012. Microbiological quality and detection of antibiotic residue in raw and pasteurized milk consumed in the Reconcavo area of the state of Bahia, Brazil. Journal of Food Processing Technology, 3, 1 doi.org/10.4172/21577110.1000137.

Department of Agriculture (US) Fort Collins (CO): USDA, Animal and Plant Health Inspection Service, Veterinary Services, National Animal Health Monitoring System; 2008.

Dhanarani, T. S., Shankar, C., Park, J., Dexilin, M., Kumar, R. R., and Thamaraiselvi, K. 
2009. Study on Acquisition of Bacterial Antibiotic Resistance Determinants in Poultry Litter. Poultry Science, 88(7):1381-87.

Diarrassouba F., Diarra M.S., Bach S., Delaquis P., Pritchard J, Topp E, et al., Antibiotic resistance and virulence genes in commensal Escherichia coli and Salmonella isolates from commercial broiler chicken farms. J Food Prot. 2007; 70: 1316-27.

Distribution and accumulative pattern of tetracyclines and sulfonamides in edible vegetables of cucumber, tomato, and lettuce. Journal of Agricultural and Food Che mistry. 2015; 63(2): 398-405

Drugs and Cosmetics Rules (2nd Amendment) G.S.R. 160(E). 2006. New Delhi: Gazette of India.

Duricic, D., Lipar, M and Samardizija, M. 2014. Ozone treatment of metritis and endometritis in Holstein cows. Vet Arhiv. 84:103-10

Durrani, A.Z., Raza, M.U and Channa, A.A. 2017. An Alternative Therapy with Ozone to Avoid Antimicrobial Resistence (AMR) in Uterine Infections in Dairy Cattle. Journal of scientific and technical research.

DOI:

10.26717/BJSTR.2017.01.000303

Eseceli H, Demir E, Degirmencioglu N and Bilgic, M. 2010. The Effect of Biomosmannan oligosaccharide and Antibiotic Growth Promoter Performance of Broilers. J. Anim. Vet. Adv. 9(2): 392395.

EU. 2015. Commission Notice No. 2015/C 299/04. Guidelines for the prudent use of antimicrobials in veterinary medicine. Official Journal of the European Union. 2015;C 299:7-29

European Economic Community (EEC), 1990. Council regulation $2377 / 90$ of 26 June 1990 laying down a community procedure for establishment of maximum residue limits of veterinary medicinal products in foodstuffs of animal origin. Off. J. Eur. Common. L., 224: 1-8.

Export Inspection Council, Ministry of
Commerce and Industry, http://www.eicindia.gov.in/knowledgerep ository/legal/pdf/Archive_2012/RMP\%20 2011-12\%20 $\% 20$ Poultry\%20Meat\%20Products.pdf

Foerster, D., Berk, A., Hoppen, H.O., Rambeck, W.A and Flachowsky, G. 2008. A note on the effect of rare earth elements on the performance and thyroid hormone status of rearing piglets. J. Anim. Feed Sci. 17:70-74.

Fontes, B., Heimbecker, A.M.C., de Souza Brito, G., Costa, S.F., van der Heijden, I.M., Levin, A.S and Rasslan, S. 2012. Effect of low-dose gaseous ozone on pathogenic bacteria. BMC Infectious Diseases. 12:358

Forsberg, K.J., Reyes, A., Wang, B., Selleck, E.M., Sommer, M.O.A and Dantas, G. 2012. The shared antibiotic resistance of soil bacteria and pathogens. Science, 337: 1107- 1111.

Fuller, R. 1977. The importance of lactobacilli in maintaining normal microbial balance in the crop. Br. Poult. Sci. 18:85-94.

Galvao, K.N., Santos, J.E., Coscioni, A., Villasenor, M., Sischo, W.M and Berge, A.C. 2005. Effect of feeding live yeast products to calves with failure of passive transfer on performance and patterns of antibiotic resistance in fecal Escherichia coli. Reproduction, Nutrition, Development 45: 427-440.

Garofalo C, Vignaroli C, Zandri G, Aquilanti L, Bordoni D, Osimani A, et al., Direct detection of antibiotic resistance genes in specimens of chicken and pork meat. Int $\mathbf{J}$ Food Microbiol. 2007;113:75-83.

Gebreyes, W. A., Thakur, S., and Morrow, W. M. 2005. Campylobacter coli: prevalence and antimicrobial resistance in antimicrobial-free $(\mathrm{ABF})$ swine production systems. Journal of antimicrobial chemotherapy, 56(4), 765768.

Ghosh, S., Mehla, R.K., Sirohi, S.K and Tomar, S.K. 2011. Performance of crossbred calves with dietary supplementation of garlic extract," Journal of Animal 
Physiology and Animal Nutrition. 4, 449455

Giger, W., Alder, A.C., Golet, E.M., Kohler, H.P.E., McArdell, C.S., Molnar, E., Siegrist, H and Suter, M.J.F. 2003. Occurrence and fate of antibiotics astrace contaminants in wastewaters, sewage sludges, and surface waters, Chimia, 57(9), 485-491

Government of India, 2006. The Food Safety and Standards Act, 2006, second ed. Commercial law publishers (India) Pvt. Ltd., India.

Griggs, J.P and Jacob, J.P. 2005. Alternatives to Antibiotics for Organic Poultry Production. J. Appl. Poult. Res. 14:750 756

Gupta, R.C. 2010. Veterinary toxicology: Basic and clinical principles. 2nd Ed, Elsevier publication, USA, 2012, 135-155.

Han, Y.K., and Thacker, P.A. 2010. Effects of antibiotics, zinc oxide or a rare earth mineral-yeast product on performance, nutrient digestibility and serum parameters in weanling pigs. AsianAustralasian Journal of Animal Sciences. 23(8), 1057-1065.

He, H., Genovese, K.J., Lowry, V.K., Nisbet, D.J and Kogut, M.H. 2006. Response of nitric oxide production to $\mathrm{CpG}$ oligodeoxynucleotides in turkey and chicken peripheral blood monocytes. FEMS Immunology \& Medical Microbiology. 48(1), 99-106.

Heberer, J. 2002. Occurrence, fate and removal of Pharmaceutical residues in the aquatic environment, a review of recent research data. Toxicol. Lett 131: 5-17.

herbs in veterinary health care. Annals of Ayurvedic Medicine. 4, 144-152.

Hogan, J.S., Smith K.L., Weiss, W.P., Todhunter, D.A and Shockey, W. L. 1990. Relationships among vitamin E, selenium, and bovine blood neutrophils. J. Dairy Sci. 73:2372-2378.

Holtcamp, W. 2011. Poultry Relief? Organic Farming May Reduce Drug Resistance. Environmental Health Perspectives, 119: a489-a489.
Jackson, G.S., 1980. Safety assessment of drug residue. J. Am. Vet. Med. Assoc., 176: 1141-1144

Jalal, K.C.A., John, B.A., Kamaruzzaman, B.Y., Kathiresan, K. In: Pana M, editor. Emergence of Antibiotic Resistant Bacteria from Coastal Environment - A Review, Antibiotic Resistant Bacteria - A Continuous Challenge in the New Millennium. InTech; 2012 ISBN: 97895351-0472-8. InTech publisher, Rijeka, Croatia-EU. http://www.intechopen. com/books/antibiotic-resistant-bacteria-acontinuous-challenge-in-thenewmillennium/emergence-of-antibioticresistant-bacteria-from-coastalenvironment-a-review

Kiarie, E., Romero, L.F and Nyachoti, CM. 2013. The Role of Added Feed Enzymes in Promoting Gut Health in Swine and Poultry. Nutrition Research Reviews, 1,71-88.

Kim, K.R., Owens, G., Kwon, S.I., So, K.H., Lee, D.B and Ok, Y.S. 2011. Occurrence and environmental fate of veterinary antibiotics in the terrestrial environment. Water, Air, Soil Pollution. 214:163-174

Koo, H., Ryu, S.H., Ahn, H.J., Jung, W.K., Park, Y.K., Kwon, N.H and Davis, W. C. 2006. Immunostimulatory effects of the anionic alkali mineral complex BARODON on equine lymphocytes. Clinical and vaccine immunology, 13(11), 1255-1266.

Kumar, A., Gill, J.P.S and Bedi, J.S. 2018. Multiresidue determination of pesticides in market honey from northern India using QuEChERS approach and assessment of potential risks to consumers. Current Science, 115(2), 283291.

Kumar, A., Patyal, A., Panda, A.K. 2018. Subtherapeutic use of antibiotics in animal feed and their potential impact on environmental and human health: a comprehensive review. Journal of Animal Feed Science and Technology, 6, 15-25. DOI: http://dx.doi.org/10.21088/jafst. 2321.1628.6118.3 
Kumar, K., Gupta, S.C., Chander, Y and Singh, A.K. 2005. Antibiotic use in agriculture and its impact on the terrestrial environment, Advances in Agronomy, 87, $1-54$

Laxminarayan, R., Van Boeckel, T., and Teillant, A. 2015. The economic costs of withdrawing antimicrobial growth promoters from the livestock sector. https://doi.org/10.1787/18156797.

Levy, S.B., 1992. The Antibiotic Paradox. How Miracle Drugs are Destroying the Miracle. Plenum Press, New York.

Manual for veterinary drug residue analysis including antibiotics, 2018. FSSAI

Markowiak, P and Śliżewska, K. 2018. The role of probiotics, prebiotics and synbiotics in animal nutrition. Gut pathogens. 10(1), 21.

Maron, D.F., Smith T.J and Nachman K.E. 2013. Restrictions on antimicrobial use in food animal production: An international regulatory and economic survey. Global Health. 9:48

Mazurek, J., Pusz, P., Bok, E., Stosik, M. and Baldy Chudzik, K. 2013. The Phenotypic and Genotypic Characteristics of Antibiotic Resistance in Escherichia coli Populations Isolated from Farm Animals with Different Exposure to Antimicrobial Agents. Polish Journal of Microbiology, 62: 173-179.

Mena C., Rodrigues D., Silva J., Gibbs P., Teixeira P. Occurrence, identification, and characterization of Campylobacter species isolated from Portuguese poultry samples collected from retail establishments. Poult Sci. 2008;87:18790.

Ministry of Health and Family Welfare. 2012. "food safety and standards (contaminants, toxins and residues) regulations, 2011." Government of India Ministry of Health and Family Welfare. http://www.fssai.gov.in/Portals/0/Pdf/Foo d $\% 20$ safety $\% 20$ and $\% 20$ standards $\% 20$ (contaminats,\%20toxins\%20and\%20resid ues)\%20 regulation, $\% 202011$.pdf.

Modesto, M., D'Aimmo, M.R., Stefanini, I.,
Trevisi, P., De Filippi, S., Casini, L and Biavati, B. 2009. A novel strategy to select Bifidobacterium strains and prebiotics as natural growth promoters in newly weaned pigs. Livestock Science, 122(2-3), 248-258.

Movassagh, M.H. and Karami, A.R. 2010. Determination of Antibiotic Residues in Bovine Milk in Tabriz, Iran. Global Veterinary Journal. 5(3), 195-97.

Murugesan, G.R., Syed, B., Haldar, S and Pender, C. 2015. Phytogenic feed additives as an alternative to antibiotic growth promoters in broiler chickens. Frontiers in veterinary science, 2, 21.

Nero, L.A., Mattos, M.R., Beloti, V., Barros, M.A.F and Franco, B.D.G.M. 2007. Residues of antibiótics in raw milk from four dairy regions in Brazil. Ciênc Tecnol Aliment Campinas, 27, 391-393.

Normanno, G., Corrente, M., Salandra, G., Dambrosio, A., Quaglia, N. C., Parisi, A. Et al., 2007. Methicillin-Resistant Staphylococcus aureus (MRSA) in Foods of Animal Origin Product in Italy. International Journal of Food Microbiology, 117(2):219-22. Cited in Marshall and Levy 2011.

O'Neill, J. 2015. Antimicrobials in agriculture and the environment: reducing unnecessary use and waste. London, UK: Review on Antimicrobial Resistance, https://amr-

review.org/sites/default/files/Antimicrobi als\%20in\%20agriculture\%20and\%20the $\% 20$ environment $\% 20$ $\% 20$ Reducing\%20unnecessary\%20use $\% 2$ 0and\%20waste.pdf

Oguttu, J.W., Veary, C.M and Picard, J.A. 2007. Antimicrobial drug resistance among poultry isolates from broilers on antimicrobials. University of South Africa, South Africa

Okele IN, Lamikanra A, Edelman R. 1999 Socioeconomic and behavioral factors leading to acquired bacterial resistance to antibiotics in developing countries. Emerg Infect Dis. 5: 18-27.

Oruganti, M. 2011. Organic Dairy Farming - A 
new Trend in Dairy Sector. Veterinary World 4(3): 128-130.

Paige, J. C., Tollefson, L and M. Miller, 1997. Public health impact on drug residues in animal tissues. Vet. Human Toxicol., 9: $1-27$.

Peric L, Zikic D and Lukic, M. 2009. Application of alternative growth promoters in broiler production. Biotechnol Anim Husbandry. 25(5-6): 387-397.

Politis, I., M. Hidiroglou, J. H. White, J. a. Gilmore, S. N. Williams, H. Scherf, and M. Frigg. 1996. Effects of vitami n $\mathrm{E}$ on mammary and blood leukocyte function with emphasis on chemotaxis in periparturient dairy cows. Am. J. Vet. Res. 468-471.

Politis, I., M. Hidiroglou, T. R. Batra, J. A. Gilmore, R. C. Gorewit, and H. Scherf. 1995. Effects of vitamin $\mathrm{E}$ on immune function of dairy cows. Am. J. Vet. Rec. 56:179-184.

Poulsen, H.D. 1995. Zinc oxide for weanling piglets. Acta Agriculturae Scandinavica A-Animal Sciences, 45(3), 159-167.

Pruden, A., Larsson, D. G. J., Amezquita, A., Collignon, P., Brandt, K. K., Graham, D. W., Lazorchak, J. R., Suzuki, S., Silley, P., Snape, J. R., Topp, E., Zhang, T., and Zhu, Y. G. 2013. Management options for reducing the release of antibiotics and antibiotic resistance genes to the environment. Environmental Health Perspectives, 121, 1-9.

Raith, J., Trauffler, M., Firth, C.L., Lebl, K., Schleicher, C., and Kofer, J. 2016. Influence of porcine circovirus type 2 vaccination on the level of antimicrobial consumption on 65 Austrian pig farms. Veterinary Record. 176(5): 124.

Ramchandani, M., Manges, A.R., Debroy, C., Smith, S.P., Johnson, J.R., Riley, L.W. 2005. Possible animal origin of human associated multidrug resistant, uropathogenic Escherichia coli. Clin Infect Dis. 40:251-7.

Ranganathan, V and Selvasubramanian, S. 2015. Evaluation of cell mediated immune response in rabbits fed with Cucurbita maxima seeds. Indian J. Anim. Res., 49 (2), 223-226

Ranganathan, V. 2017. Ethno Veterinary Practices for Combating Antimicrobial Resistance. International Journal of Science, Environment and Technology. 6 (1):840 - 844

Redling, K. 2006. Rare earth elements in agriculture with emphasis on animal husbandry. Diss. Ludwig-MaximiliansUniversitaet, Muenchen, p. 325.

Robinson, T. P., Bu, D. P., Carrique-Mas, J., Fevre, E. M., Gilbert, M., Grace, D., Hay, S.I., Jiwakanon, J., Kakkar, M., Kariuki, S. and Laxminarayan, R. 2016. Antibiotic resistance is the quintessential One Health issue. Transactions of the Royal Society of Tropical Medicine and Hygiene, 110(7), 377-380.

Roodpshti, P.M and Dabri, N. 2012. Effects of Probiotic and Prebiotic on Average Daily Gain, Fecal Shedding of Escherichia Coli, and Immune System Status in Newborn Female Calves. Asian-Aust. J. Anim. Sci. 25 (9): $1255-61$

Saad, M.M. 2016. The risk of human exposure to antibiotic residues from food of both animal and plant origin. European Journal of Biomedical and Pharmaceutical Sciences. 3(5):12-15

Sahu, S.K and Maiti, S.K. 2014. Prepartum micronutrient supplementation and its effect on control of subclinical mastitis. Intas polivet. 15(2): 185-87

Sapkota, A.R., Hulet, R.M., Zhang, G., McDermott, P., Kinney, E.L., Schwab, K.J and Joseph, S.W. 2011. Lower prevalence of antibiotic-resistant enterococci on US conventional poultry farms that transitioned to organic practices. Environmental health perspectives. 119(11), 1622.

Sarmah, A.K., Meyer, M.T., and Boxall, A.B. 2006. A global perspective on the use, sales, exposure pathways, occurrence, fate and effects of veterinary antibiotics (VAs) in the environment. Chemosphere, 65(5), 725-759. 
Sharma R., Larney F.J., Chen J., Yanke L.J., Morrison M., Topp E., et al., 2009. Selected antimicrobial resistance during composting of manure from cattle administered subtherapeutic antimicrobials. J Environ Qual. 38:567575

Shinozuka, Y., Uematsu, K., Takagi, $\mathbf{M}$ and Taura, Y. 2008. Comparison of the amounts of endotoxin released from Escherichia coli after exposure to antibiotics and ozone: an in vitro evaluation. Journal of Veterinary Medical Science. 70(4): 419-422

Shivachandra. J.B., Kumar, A.A., Biswas, A., Ramakrishnan, M.A., Singh, V.P. and Srivstava, S.K. 2004. Antibiotic sensitivity patterns among Indian strains of avian pasteurella multocida. Tropical animal health and production. 36, 743750

Silbergeld E.K., Graham J and Price L.B. 2008. Industrial food animal production, antimicrobial resistance, and human health. Annu Rev Public Health. 29:151169

Stanton, A.L., Kelton, D.F., LeBlanc, S.J., Millman, S.T., Wormuth, J., Dingwell, R and Leslie, K.E. 2010. The effect of treatment with long-acting antibiotic at postweaning movement on respiratory disease and on growth in commercial dairy calves. Journal of Dairy Science. 93(2):574-581

Storteboom, H. N., Kim, S.C., Doesken, K.C., Carlson, K.H., Davis, J.G and Pruden, A. 2007. Response of antibiotics and resistance genes to high-intensity and low-intensity manure management. Journal of Environmental Quality, 36(6), 1695-1703.

Thacker, P.A. 2013. Alternatives to antibiotics as growth promoters for use in swine production: a review. Journal of animal science and biotechnology, 4(1), 35.

Thiele-Bruhn, S. 2003. Pharmaceutical Antibiotic Compounds in Soils- A Review. Journal of Plant Nutrition, 166, (2), 145-16.
Tho Seeth, M., Wente, N., Paduch, J. H., Klocke, D., Mansion-de Vries, E., Hoedemaker, M., and Krömker, V. (2017). Different selective dry cow therapy concepts compared to blanket antibiotic dry cow treatment. Tierärztliche Praxis G: Großtiere/Nutztiere, 45(06), 343-349.

Timmerman, H.M., Mulder, L., Everts, H., vanEspen, D.C. van der Wal, E., Klaassen, G., Rouwers, S.M., Hartemink, R., Rombouts, F.M and Beynen, A.C. 2005. Health and growth of veal calves fed milk replacers with or without probiotics. Journal of Dairy Science, 88: 2154-2165.

Trevisi, E., Zecconi, A., Cogrossi, S., Razzuoli, E., Grossi, P and Amadori, M. 2014. Strategies for reduced antibiotic usage in dairy cattle farms. Research in Veterinary Science. 2014; 96(2): 229-233

Upadhaya, S.D., Lee, K.Y and Kim, I.H. 2014. Protected organic acid blends as an alternative to antibiotics in finishing pigs. Asian-Australasian journal of animal sciences, 27(11), 1600.

Vakili, A.R., Khorrami, B., Danesh, M.M and Parand, E. 2013. The Effects of Thyme and Cinnamon Essential Oils on Performance, Rumen Fermentation and Blood Metabolites in Holstein Calves Consuming High Concentrate Diet. Asian-Australasian Journal of Animal Sciences. 7, 935-44

Van de Weerd, H. A., Keatinge, R., and Roderick, S. 2009. A review of key health-related welfare issues in organic poultry production. World's Poultry Science Journal, 65(4), 649-684.

Wang L., Oda Y., Grewal S., Morrison M., Michel F and Yu Z. 2012. Persistence of resistance to erythromycin and tetracycline in swine manure during simulated composting and lagoon treatments. Microb Ecol. 63:32-40.

Wang, S., Zeng, X., Yang, Q and Qiao, S. 2016. Antimicrobial peptides as potential alternatives to antibiotics in food animal industry. International journal of 
molecular sciences, 17(5), 603.

Wary, C. and Gnanou, J. 2000. Antibiotic resistance monitoring in bacteria of animal origin analysis of national monitoring programs. Int. J. Antimicirob. Agents, 14: 291-294.

Weiner, G.J., Liu, H.M., Wooldridge, J.E., Dahle, C.E and Krieg, A.M. 1997. Immunostimulatory oligodeoxy nucleotides containing the $\mathrm{CpG}$ motif are effective as immune adjuvants in tumor antigen immunization. Proceedings of the National Academy of Sciences. 94(20), 10833-10837.

WHO. 2014. Antimicrobial resistance: global report on surveillance 2014. http://apps.who.int/iris/bitstream/10665/1 12642/1/9789241564748_eng.pdf?ua=1

Wierup, M. 2001. "The Swedish Experience of the 1986 Year Ban of Antimicrobial Growth Promoters, with Special
Reference to Animal Health, Disease Prevention, Productivity, and Usage of Antimicrobials." Microbial Drug Resistance, 7: 183-90.

Windisch W, Schedle K, Plitzner C, Kroismayr A.. Use of phytogenic products as feed additives for swine and poultry. $\mathrm{J}$ Anim Sci (2007) 86:E140-8.10.2527/jas.20070459

Yang, C., Kabir, C.M.A., Hou, Y and Gong, J. 2015. Phytogenic compounds as alternatives to in-feed antibiotics: potentials and challenges in application. Pathogens. 4:137-56.

Zhang, Y., Lee, B. Y., Donohue, J. M. 2010. Ambulatory Antibiotic Use and Prescription Drug Coverage in Older Adults. Archives of Internal Medicine, 170(15): 1308-14.

\section{How to cite this article:}

Ankaj Thakur, Atul Kumar, Manoj Sharma, Rohit Kumar and Brij Vanita. 2019. Strategies to Minimize the Impact of Antibiotic Resistance in Livestock Production System. Int.J.Curr.Microbiol.App.Sci. 8(03): 2293-2310. doi: https://doi.org/10.20546/ijcmas.2019.803.273 